\title{
Postharvest foliar nitrogen applications increase Neonectria ditissima leaf scar infection in apple trees
}

\author{
G.H. Dryden ${ }^{1}$, M.A. Nelson ${ }^{1}$, J.T. Smith ${ }^{2}$ and M. Walter ${ }^{3}$ \\ ${ }^{1}$ Fruition Horticulture, PO Box 3194, Richmond, 7050, New Zealand \\ ${ }^{2}$ HortEye, Bullen St, Tahunanui, Nelson, 7011, New Zealand \\ ${ }^{3}$ The New Zealand Institute for Plant \& Food Research Limited, \\ Old Mill Road, RD3, Motueka 7198, New Zealand \\ Corresponding author: monika.walter@plantandfood.co.nz
}

\begin{abstract}
Postharvest foliar nitrogen (urea) is often applied to apple leaves immediately after picking for bud fertilising, and/or during leaf fall for Venturia inaequalis control. During 2013-2016, ethylene diamine tetra-acetic acid copper (EDTA-Cu, to enhance leaf abscission), urea, calcium nitrate and Bud-Wiser ${ }^{\text {Tw }}$ foliar treatments were applied alone or in combination to determine their effects on leaf scar infection by Neonectria ditissima in 'Braeburn' (2013-14), 'Scifresh' and 'Royal Gala' (2015-16) orchards. In 2013-14, leaf scar infection increased six-fold when 5\% urea was added to EDTA-Cu and sprayed at the onset of leaf fall. In 2015-16, up to a nine-fold increase in leaf scar infections was observed. The timing of application was more important than the amount or form of nitrogen used. As a result of this research, the use of urea-based foliar nitrogen fertilisers for $V$. inaequalis before leaf fall are not recommended, and growers should consider all factors affecting Neonectria ditissima infections before applying nitrogen immediately after harvest.
\end{abstract}

Keywords European canker, Nectria galligena, fertiliser, picking wound

\section{INTRODUCTION}

European canker, caused by Neonectria ditissima, is a tree health problem in pipfruit production areas with temperate and wet climates (Beresford \& Kim 2011). In New Zealand orchards, it has been standard management to apply postharvest foliar urea to apple trees. This is applied either immediately after picking, for bud fertilisation, to enhance bud development and to support growth in the following spring (Dong et al. 2002a), or applied during early leaf fall for management of Venturia inaequalis inoculum, the cause of apple black spot (Beresford et al.
2000). Urea at $2-5 \%$ dilution is the most common form of nitrogen applied for these purposes.

Leaf scars are a major entry point for N. ditissima infections (Swinburne 1975; Weber 2014). Application of ethylene diamine tetra-acetic acid copper (EDTA-Cu) effectively accelerates leaf-fall (Dong et al. 2002b) and shortens the time required for leaf scar protection against $N$. ditissima infection. The aim of three field trials reported here was to determine the effects of nitrogen, as either urea or calcium nitrate with or without EDTA-Cu, on leaf scar susceptibility to $N$. ditissima. 


\section{MATERIALS AND METHODS Field trials}

Three field trials were conducted on cultivars 'Braeburn' (2013-14 growing season), 'Royal Gala' and 'Scifresh'/Jazz' (both in 2015-16) in the Tasman region of the South Island, New Zealand (Table 1). Trial 1 was conducted on mature, centre leader 'Braeburn' trees at the Plant \& Food Research orchard, Riwaka; Trials 2 and 3 were conducted on grower properties in Mariri and Waimea, respectively. In Trial 2, the trees were managed with a centre leader semi-intensive system, while for Trial 3 they were in a mature vertical axis intensive system. The treatments were identical in Trials 2 and 3. Treatments were applied by motorised knapsack (Echo-170SI) at 1700 (Trial 1), 1600 (Trial 2), or 1200 (trial 3) litres of water/ha. Trees were sprayed to achieve good leaf coverage (but not run-off), and water rates were adjusted according to canopy and tree height (i.e. variable rate spraying). The treatments in the three trials were replicated three (Trial 1) and four (Trials 2 and 3) times and arranged randomly (Trial 1) and in randomised complete blocks (Trials 2 and 3). Plots consisted of five trees (Trial 1) and two trees (Trials 2 and 3), with a tree at each end of each plot as guard trees.

The dates of each treatment application for both trial locations are shown in Table 2. For the after-picking spray applications, treatments were applied the day following the completion of fruit harvesting.

\section{Wounds and inoculation}

In Trial 1, treatments were applied at the commencement of natural leaf fall. Leaf scars were created 10 days after treatment application by removing three (preferably senescent) leaves per shoot. Selected shoots were labelled and leaf scars marked with a paint pen (Walter et al. 2015). In each plot, there were up to 30 shoots which were inoculated with a $N$. ditissima spore suspension (ca $1 \times 10^{5}$ conidia $/ \mathrm{ml}$ ), prepared from naturally occurring canker lesions, as described by Walter et al. (2015).

In Trials 2 and 3, in each plot 30 spurs with 1-2 picking wounds per spur were selected and tagged for after-picking inoculations. Trial 2 was inoculated on 14 March 2015 and Trial 3 on 3 April, following the application of the nitrogen treatments (Table 2). All 30 picking wounds were inoculated with freshly made spore suspensions of $N$. ditissima (adjusted to $1 \times 10^{5}$ conidia/ml concentration), as described above.

For the leaf fall applications, leaf scars were made after the spray treatments. In each plot, 32 shoots were selected and three leaf scars per shoot were inoculated and tagged for the leaf scar inoculations. Trials 2 and 3 were inoculated on 21 May with freshly-made spore suspensions $\left(1 \times 10^{5}\right.$ conidia $\left./ \mathrm{ml}\right)$. At the Trial 3 site a further 40 shoots were tagged and inoculated with a 10 -fold dilution rate of $1 \times 10^{4}$ conidia $/ \mathrm{ml}$.

For all spur and leaf scar inoculations ca $20 \mu \mathrm{l}$ of spore suspension was applied to each wound using the droplet-brush method described by Walter et al. (2015). Assessments for European canker incidence were made monthly, with a final assessment in February 2016. Infected shoots (and spurs) arising from artificial inoculations were enumerated and removed at each assessment (even if only one leaf scar showed symptoms).

\section{Nitrogen concentrations}

On 17 March (Trial 2) and 7 April 2015 (Trial 3), 24 non-inoculated picking scars (whole spurs) were randomly selected, removed from each plot, placed in separate bags and frozen. Twenty-four leaf scar and bud samples (leaf scars+buds) were similarly collected on 23 May (Trial 2) and 4 June 2015 (Trial 3). Leaf scars and buds were excised with a craft knife by making a $\mathrm{V}$-cut. Both tissue types were then analysed at Hills Laboratories Limited, Ruakura, New Zealand, for percentage nitrogen content.

\section{Fruit set assessments}

In all three trials, for each plot, 20 branches were selected and counts made of numbers of flower 
Table 1 Treatments, growth stages and application timing of nitrogen and ethylene diamine tetraacetic acid copper (EDTA-Cu) to apple trees in three field trials.

\begin{tabular}{|c|c|c|}
\hline Treatments & Growth stage & kg N/ha applied \\
\hline \multicolumn{3}{|l|}{ Trial 1 (2013-14) } \\
\hline 1. Unsprayed control & - & 0 \\
\hline 2. EDTA-Cu granular $400 \mathrm{~g} / 100$ litres $+5 \%$ urea $^{1}$ & $5 \%$ Leaf fall & 46 \\
\hline 3. EDTA-Cu liquid $800 \mathrm{ml} / 100$ litres $+5 \%$ urea $^{2}$ & $5 \%$ Leaf fall & 46 \\
\hline 4. EDTA-Cu granular $400 \mathrm{~g} / 100$ litres & $5 \%$ Leaf fall & 0 \\
\hline 5. EDTA-Cu liquid $800 \mathrm{ml} / 100$ litres & $5 \%$ Leaf fall & 0 \\
\hline 6. EDTA-Cu granular $400 \mathrm{~g} / 100$ litres+captan ${ }^{3}$ & $5 \%$ Leaf fall & 0 \\
\hline
\end{tabular}

\section{Trials 2 and 3 (2015-16)}

1. Unsprayed control

2. EDTA-Cu granular $400 \mathrm{~g} / 100$ litres $+5 \%$ urea

$\begin{array}{ll} & 0 \\ 5 \% \text { Leaf fall } & 46 \\ 5 \% \text { Leaf fall } & 46 \\ 5 \% \text { Leaf fall } & 18.4 \\ 5 \% \text { Leaf fall } & 18.6 \\ \text { After picking } & 18.4 \\ \text { After picking } & 18.4 \\ \text { After picking } & 18.6 \\ \text { After picking } & 18.6\end{array}$

3. $5 \%$ urea

4. $2 \%$ urea

5. Calcium nitrate $6 \%{ }^{4}$

6. $2 \%$ urea

7. $2 \%$ urea+Bud-Wiser ${ }^{\mathrm{Tm}} 7 \mathrm{~kg} / \mathrm{ha}^{5}$

8. Calcium nitrate $6 \%$

9. Calcium nitrate $6 \%+$ Bud-Wiser $7 \mathrm{~kg} / \mathrm{ha}$

After picking

18.6

${ }^{1}$ EDTA-Cu was a granulated product $(14 \% \mathrm{Cu} w / w)$ marketed as Librel ${ }^{\oplus}$ (BASF). Urea was supplied by Fruitfed mixed in at $5 \%$ or $5 \mathrm{~kg} / 100$ litres

${ }^{2}$ EDTA-Cu was a liquid product $\left(14 \% \mathrm{Cu}\right.$ w/w) marketed as GroChem Trace-it ${ }^{\mathrm{int}} \mathrm{Cu}$ (GroChem)

${ }^{3}$ Captan (Fruitfed Captan $800 \mathrm{WG}$ ) was used at $1.2 \mathrm{~kg}$ product per hectare

${ }^{4}$ Calcium nitrate was provided by Fruitfed

${ }^{5}$ Bud-Wiser (GroChem) is a postharvest foliar trace element containing boron, zinc and magnesium

clusters. Once fruit set was complete (just before hand thinning in December), the number of fruit and branch cross-sectional areas (BCA) were recorded. An indication of fruit set was calculated as the number of fruit per original number of flower clusters per $\mathrm{cm}^{2}$ of BCA.

\section{Statistical analysis}

Where appropriate, data were subjected to analysis of variance (ANOVA) using the statistical package $R$, and a scatter plot of the residuals was examined for deviation from the ANOVA assumptions. Differences in treatment means were determined by conducting Fisher's LSD test $(\mathrm{P}<0.05)$. Coefficients of variation as a percentage $(\mathrm{CV} \%)$ were calculated for all variables analysed.

\section{RESULTS Nitrogen concentrations}

Nitrogen concentrations in spurs were overall greater in Trial 2 ('Royal Gala') than in Trial 3 ('Scifresh'/Jazz $\left.{ }^{\mathrm{TM}}\right)(\mathrm{P}<0.05)$ (Table 3). Generally, all treatments resulted in higher mean percentage of nitrogen in treated spurs compared with the unsprayed control, although the differences were not significant $(\mathrm{P}>0.05)$. Similarly, nitrogen concentrations in leaf scars following the leaf-fall applications were generally greater in Trial 2 ('Royal Gala') than in Trial 3 ('Scifresh') $(\mathrm{P}<0.05)$. However, in both trials there was a significant treatment effect for nitrogen concentration in leaf scars (Trial $2 \mathrm{P}=0.046$, Trial $3 \mathrm{P}=0.031$ ). In both trials the EDTA-Cu+5\% 
Table 2 Nitrogen application dates to apple trees for each growth stage in three field trials at Riwaka (2013), Mariri and Waimea (2015).

\begin{tabular}{lll}
\hline Site & After picking & Leaf-fall \\
\hline Trial 1, Riwaka & - & 28 May 2013 \\
Trial 2, Mariri & 13 March 2015 & 19 May 2015 \\
Trial 3, Waimea & 2 April 2015 & 20 May 2015 \\
\hline
\end{tabular}

Table 3 Nitrogen $(\mathrm{N})$ concentration in apple spurs and leaf scars+bud samples sprayed with foliar fertilisers. Spurs were collected 4 days after treatment application (ATA) in Trial 2, and 5 days ATA in Trial 3. Leaf scar samples were collected 16 days ATA in Trial 2 and 17 days ATA in Trial 3. Treatments are described in Table 1.

\begin{tabular}{lcccc}
\hline Treatments & \multicolumn{2}{c}{$\begin{array}{l}\text { N (\%) in spurs } \\
\text { applied after picking }\end{array}$} & \multicolumn{2}{c}{$\begin{array}{c}\text { N (\%) in leaf scars+buds applied } \\
\text { after picking or early leaf fall }\end{array}$} \\
\hline & Trial 1 & Trial 2 & Trial 3 & Trial 4 \\
\hline 1. Unsprayed control & 1.73 & 1.39 & 1.48 & 1.39 \\
2. EDTA-Cu+5\% urea & & & 1.63 & 1.55 \\
3. 5\% urea & & & 1.56 & 1.53 \\
4. 2\% urea & & & 1.54 & 1.42 \\
5. Calcium nitrate & 1.82 & 1.42 & 1.46 & 1.52 \\
6. 2\% urea & 1.85 & 1.36 & 1.48 & 1.41 \\
7. 2\% urea+Bud-Wiser ${ }^{\mathrm{Tm}}$ & 1.87 & 1.45 & 1.43 & 1.51 \\
8. Calcium nitrate & 2.03 & & 1.42 & 1.47 \\
9. Calcium nitrate+Bud- & & 1.51 & 1.48 & \\
Wiser & & & & 0.031 \\
& & & & 0.11 \\
F Probability & 0.08 & 0.58 & 0.046 & 5.1 \\
LSD & 0.20 & - & 0.13 & \\
\%CV & 7 & 9.5 & 5.8 & \\
\hline
\end{tabular}

urea applied at leaf fall resulted in a higher bud nitrogen content than in the control leaf scars (Trial $21.63 \%$ vs $1.48 \%$, Trial $31.55 \%$ vs $1.39 \%$ nitrogen, respectively). In both trials the second highest leaf scar nitrogen content was produced by the $5 \%$ urea treatment applied at leaf-fall. While not statistically different from the untreated control in Trial 2, this difference was significant in Trial 3. For the other nitrogen treatments there was no difference in leaf scar nitrogen concentration between any of the treatments and the control $(\mathrm{P}>0.05)$.

\section{Picking scar lesions}

Mean incidence of spur canker from picking scar infections ranged from 1.8 to 4.5 per plot in Trial 2 and 14 to 16.3 per plot in Trial 3. There were no significant differences between treatments at either site $(\mathrm{P}>0.5$, data not shown)

\section{Leaf scar lesions}

In Trial 1, there were no differences in leaf scar lesions $(\mathrm{P}>0.05)$ between treatments not containing urea, with 1.7 to 8.7 lesions expressing symptoms per plot. However, the EDTA-Cu+5\% urea treatments resulted in significantly more lesions $(\mathrm{P}<0.001)$ than the other treatments, 


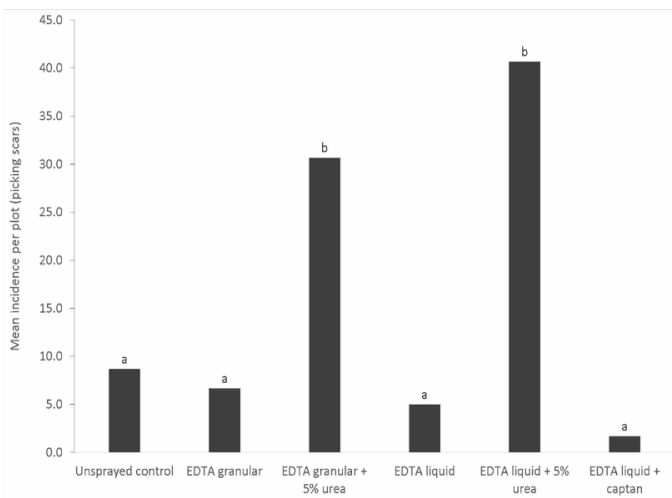

Figure 1 Trial 1: Mean numbers of European canker lesions/plot arising from artificial apple leaf scar infections following different EDTA$\mathrm{Cu}$ applications with and without urea. Refer to Table 2 for full treatment descriptions. Means accompanied by the same letter are not significantly different $(\alpha>0.05)$.

with means of 30.7 and 40.7 inoculated wounds per plot expressing symptoms, respectively, for the granular and the liquid formulations. There was no difference in leaf scar infections $(\mathrm{P}>0.05)$ between the two EDTA-Cu treatments (Figure 1).

Similarly in Trials 2 and 3 , significant $(\mathrm{P}<0.001)$ treatment differences in leaf scar disease incidence were observed. All the nitrogen treatments resulted in more European canker lesions than in the untreated controls (Figure 2). All treatments applied at leaf-fall increased disease incidence compared with incidence in the untreated controls. For the 5\% urea-only treatment, this was more than a nine-fold increase in disease. For the $2 \%$ urea-only treatment, there was seven-fold increase in disease. The EDTA-Cu+5\% urea treatment resulted in less than half the incidence of infected leaf scars that was seen in the 5\% urea-only treatment. The $6 \%$ calcium nitrate treatment applied at leaf fall in Trial 2 resulted in a four-fold increase in canker incidence (Figure 2).

At the Trial 2 site, the lower rate of inoculum resulted in fewer infected buds than the standard concentration, although the pattern among treatments was very similar. The low inoculum rate also resulted in a significant

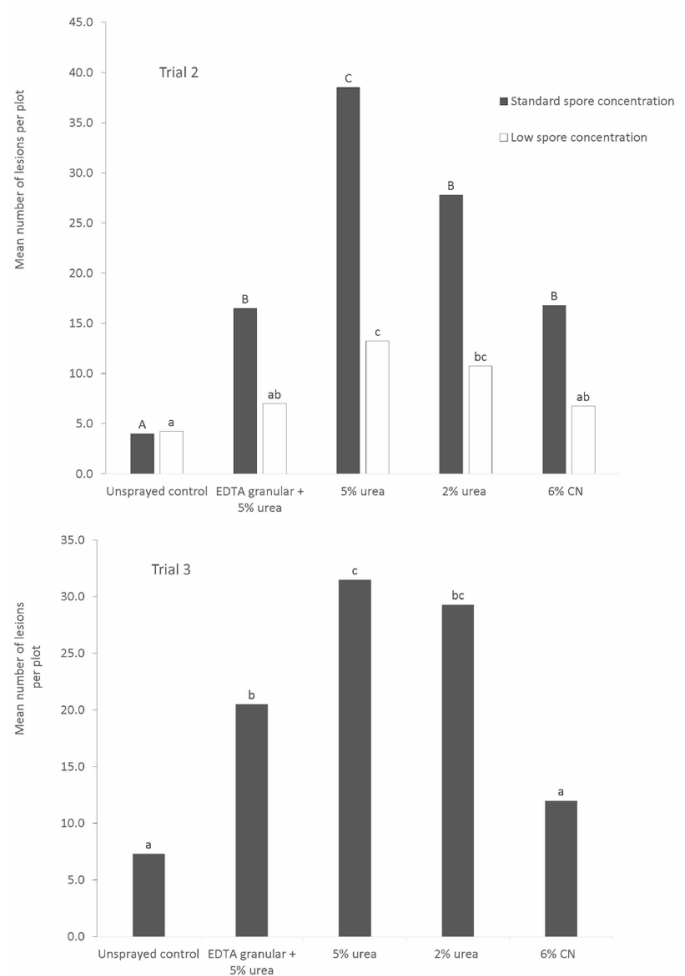

Figure 2 Trial 2 (top) and Trial 3 (bottom): Mean numbers of European canker lesions/plot arising from artificial apple leaf scar inoculation following different foliar fertiliser applications at early leaf fall. Refer to Table 2 for full treatment descriptions. Trial 2 was 'Royal Gala' and Trial 3 was 'Scifresh'/Jazz ${ }^{\mathrm{Tm}}$. Means accompanied by the same letter are not significantly different $(\alpha>0.05)$. Standard and low conidium concentrations were $1 \times 10^{5}$ and $1 \times 10^{4}$ conidia $/ \mathrm{ml}$, respectively.

$(\mathrm{P}<0.001)$ treatment effect, with both the $5 \%$ and $2 \%$ urea treatments applied at leaf-fall having more than twice the shoot canker incidence recorded than in the untreated control. Disease incidences in other treatments were no different $(\mathrm{P}>0.05)$ to the untreated control (Figure 2).

In Trials 2 and 3, treatment applications after picking did not result in different numbers of leaf scar cankers between the untreated control and the nitrogen treatments $(\mathrm{P}>0.05)$. However, the $2 \%$ urea application in both trials resulted 


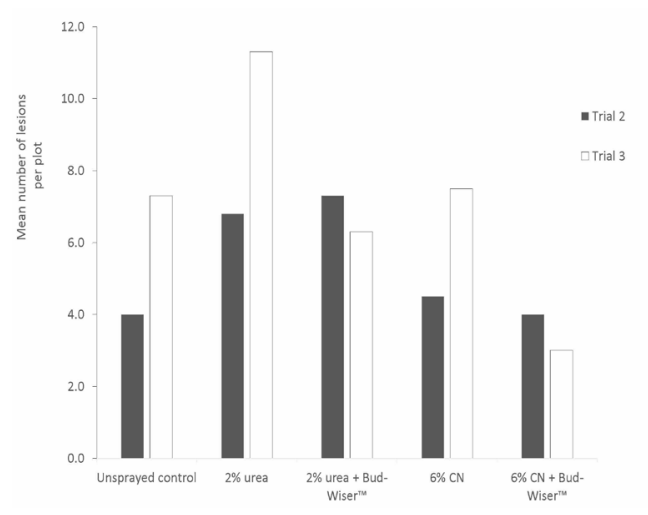

Figure 3 Trials 2 and 3: Mean numbers of European canker lesions/plot arising from artificial apple leaf scar inoculation following different foliar fertiliser applications immediately after picking. Refer to Table 2 for full treatment descriptions. Trial 2 was 'Royal Gala' and Trial 3 was 'Scifresh'/Jazz ${ }^{\mathrm{m}}$. CN = Calcium nitrate. There were no significant differences (alpha>0.05) among treatments for each site.

in greater (nearly double) European canker incidence of leaf scars (Figure 3), although this effect was not statistically significant.

\section{Fruit set}

There were no treatment effects $(\mathrm{P}>0.05)$ on fruit set in any of the trials. In Trial 2, however, there was a significant treatment response $(\mathrm{P}=0.013)$ for mean fruit number per branch circumference area. The treatments of EDTA-Cu+5\% urea at leaf-fall and $6 \%$ calcium nitrate+Bud-Wiser ${ }^{\mathrm{TM}}$ applied after picking resulted in greater mean numbers of (respectively) 18 and 16.9 fruit per $\mathrm{cm}^{2}$ BCA than recorded for the untreated control (12.9 fruit per $\mathrm{cm}^{2} \mathrm{BCA}$ ). These were, respectively, $40 \%$ and $31 \%$ increases in fruit number per BCA.

\section{DISCUSSION}

The application of nitrogen at early leaf-fall increased European canker lesion development from leaf scar inoculation by up to nine times. Increased disease incidence resulted from all forms and concentrations of nitrogen tested. Disease incidence was greatest for urea, which is commonly used at leaf-fall for black spot control. The nitrogen residues in leaf scars were elevated after leaf fall nitrogen applications. The role of nitrogen in $N$. ditissima infections is unclear. Over and under supply of nitrogen in plants has been associated with increased infections in other pathosystems (Huber \& Watson 1974). Generally, obligate and biotrophic pathogens respond differently to nitrogen concentrations in plants compared with necrotrophic pathogens, with an increase in susceptibility of plants to biotrophs, and a decrease in susceptibility of plants to necrotrophs (as reviewed by Fagard et al. 2014). While the modes of action remain unclear for many pathosystems, the authors describe how pathogen virulence may be affected by the nutritional status of the plant.

In the case of urea, both the supplemental nitrogen and the additional tissue damage by urea (Wood et al. 2008) may make the plant tissue more susceptible to infection, and result in increased symptom development. Wood et al. (2008) have reported that urea concentrations $>5 \%$ cause bud damage. Increased plant vigour resulting from soil applied fertilisers has been associated with increased apple tree susceptibility to $N$. ditissima infections (Swinburne 1975). To our knowledge, however, the effect of foliar applied nitrogen on N. ditissima infection has not been studied previously.

Timing of the nitrogen application is of importance, with fewer leaf scars developing from the earlier after-picking nitrogen application compared with the later during leaf fall application. More data will be required to validate the lack of risk from post-picking nitrogen bud fertilization on leaf scar and picking wound susceptibility. Caution should still be exercised in applying foliar nitrogen to trees, especially in blocks with histories of moderate to high rates of European canker. Further research investigating postharvest application of nitrogen to the soil, and the effects of this on 
European canker infection, should be considered.

In combination with nitrogen, less disease developed where EDTA-Cu was applied, suggesting that premature leaf abscission may also have affected the amount of foliar-applied nitrogen translocated to the bud area of treated trees. More work on nutrient translocation and long-term bud fertility using EDTA-Cu is needed. Fruit set was affected neither by EDTA-Cu-assisted leaf abscission, nor by the lack of application of postharvest foliar nitrogen. This indicates a limited benefit of postharvest foliar nitrogen sprays, in terms of increased fruit set and yield other than under nutrient-deficient growth conditions (Dong et al. 2002a). Nitrogen supplements are not always required as shown by Reay (1988). Yield in 'Granny Smith' apple trees that had not had nitrogen applied for 20 years remained unaffected and were consistently producing more than $100 \mathrm{t}$ of fruit per hectare. Nutrient calculations suggested that only a small amount of nitrogen was required to top up nitrogen inputs from natural sources, such as nitrogen fixation and breakdown of organic matter. Fisher (1952) reported that trees receiving three foliar urea applications had yields similar to those with a similar amount of nitrogen applied to the soil. Assessment of the necessity for foliar nitrogen applications to provide quality fruit production in modern production systems was beyond the scope of this study.

The amount and type of nitrogen applied also affected leaf scar susceptibility to $N$. ditissima infections and symptom development. More leaf scars developed lesions in treatments consisting of $5 \%$ urea $\geq 2 \%$ urea $\geq 6 \%$ calcium nitrate for $46,18.4$ and $18.6 \mathrm{~kg}$ nitrogen $/$ ha, respectively. Further research is needed to understand these interactions and relationships.

In conclusion, foliar application of nitrogen at leaf fall nitrogen for black spot control should be avoided in blocks at risk of $N$. ditissima infections. Urea for black spot control can be made onto the fallen leaves on the ground (Beresford et al. 2000) without increasing the risk of European canker lesion development. EDTA-Cu applications shortened the leaf fall period and reduced $N$. ditissima infections and lesion development without adversely affecting return bloom and fruit set. As a result of this research many New Zealand growers have largely stopped using urea-based foliar nitrogen fertilisers before leaf fall, and consider other factors affecting $N$. ditissima infections before applying nitrogen immediately after harvest (Walter et al. 2016).

\section{ACKNOWLEDGEMENTS}

We thank Edenbank Orchards and Wairepo Holdings for allowing these trials on their properties. Fruition Horticulture and Plant \& Food Research technical staff assisted with all the field work associated with these trials. Mr Tim Herman provided helpful review and comments for this paper. The research reported here was funded by Pipfruit New Zealand Inc.

\section{REFERENCES}

Beresford RM, Kim KS 2011. Identification of regional climatic conditions favorable for development of European canker of apple. Phytopathology 101: 135-146.

Beresford RM, Horner IJ, Wood PN 2000. Autumn-applied urea and other compounds to suppress Venturia inaequalis ascospore production. New Zealand Plant Protection 53: 387-392.

Dong S, Cheng L, Scagel CF, Fuchigami LH 2002a. Nitrogen absorption, translocation and distribution from urea applied in autumn to leaves of young potted apple. Tree Physiology 22: 1305-1310.

Dong S, Cheng L, Fuchigami LH 2002b. Effects of urea and defoliant-CuEDTA in a single of a mixed application on $\mathrm{N}$ reserves and regrowth performance of young 'Fuji'/M26 apple trees. Acta Horticulturae 636: 29-34.

Fagard M, Launay A, Clément G, Courtial J, Dellagi A, Farjad M, Krapp A, Soulié MC, Masclaux-Daubresse C 2014. Nitrogen metabolism meets phytopathology. Journal of Experimental botany doi:10.1093/jxb/eru323.

Fisher EG 1952. The principles underlying foliage applications of urea for nitrogen fertilization 
of 'McIntosh' apple. Proceedings of the American Society of Horticultural Science 59: 91-98.

Huber DM, Watson RD. 1974. Nitrogen form and plant disease. Annual Review of Phytopathology 12, 139-165.

Reay P 1988. 'Granny Smith' apple colour (green) as affected by urea. Report to NZ Apple and Pear Marketing Board.

Swinburne TR 1975. European canker of apple (Nectria galligena). Review of plant pathology 54: 787-799.

Walter M, Stevenson OD, Amponsah NT, Scheper RWA, Rainham DG, Hornblow CG, Kerer U, Dryden GH, Latter I. Butler RC 2015. Control of Neonectria ditissima with copper based products in New Zealand. New Zealand Plant Protection 68: 241-249.
Walter M, Roy S, Campbell R, Butler R, Dryden G, Smith J, Gaskin R, Manktelow D, Northcott G, Rainham D. 2016. Mitigating European canker (Neonectria ditissima) risk: a pathway to eradication. A Plant \& Food Research report prepared for: Pipfruit New Zealand Inc.. Contract No.30138. PFR Job code: P/341051/01. Client ref: SFF13-040. PFR SPTS No. 12705. February 2016. Pp 53.

Weber RWS 2014. Biology and control of the apple canker fungus Neonectria ditissima (syn. N. galligena) from a Northwestern European perspective. Erwerbs-Obstbau: DOI 10.1007/s10341-014-0210-x.

Wood PN, Beresford RM, Taylor TJ 2008. Suppression of Venturia inaequalis (apple scab) ascospore production using autumnapplied fungicides. New Zealand Plant Protection 61: 54-58. 